\title{
Sexual Dimorphism in Red-Eared Sliders (Trachemys scripta elegans) from the Wild Animal Triage Center of the Tiete Ecological Park, São Paulo, Brazil
}

\author{
Adriana Gradela', Thamyris Oliveira Carneiro Santiago', Isabelle Caroline Pires', \\ Alequisandra de Castro Souza Silva', Leniker Cordeiro de Souza', Marcelo Domingues de Faria', \\ Joaquim Pereira $\mathrm{Neto}^{2}$ \& Liliane Milanelo ${ }^{3}$
}

\begin{abstract}
Background: Trachemys scripta elegans is an aquatic turtle native to North America and distributed geographically from the eastern United States to northeastern Mexico. In Brazil, it is an exotic and invasive species and the most illegally traded pet animal. When these turtles grow and they cease to be attractive as pets, they are released clandestinely in lakes, ponds, rivers, and other bodies of water, where they threaten biodiversity and native populations. The present study aimed to characterize specimens of T. s. elegans from the Centro de Triagem de Animais Silvestres do Parque Ecológico do Tiete by analyzing body biometrics, sexual dimorphism, and structure of specimens for sex ratio and size classes.

Materials, Methods \& Results: Trachemys scripta elegans turtles (39 females and 30 males) were anesthetized, euthanized and frozen. After being thawed, the turtles were sexed according to measurements on secondary sex characters such as claw length (CWL) of the third finger of the right forearm and length of the tail from the tip to the beginning of the cloacal opening (postcloacal tail length, PTL); subsequently, sex was confirmed through dissection. Subsequently, body mass (BM, g) and maximum carapace length (MCL, cm), maximum carapace width (MCW, cm), maximum plastron length (MPL, $\mathrm{cm}$ ), maximum plastron width (MPW) and shell height (HGT, $\mathrm{cm}$, measured laterally until obtaining the greatest value) were evaluated and the sexual dimorphism index (SDI) was also calculated. All analyses were performed using SAS v. 9.4 software. The results indicate a sex ratio of 1.3 females per male. The identification of males by secondary sex characteristics was performed using only claw length (CWL), which was related to sex and not to maximum carapace length (MCL). The most discriminatory variables were CWL in males and body mass (BM) in females. With the exception of CWL, the sexual dimorphism index (SDI) values all favored females and varied from 1.21 to 2.49, with the greatest value for BM and the lowest value for postcloacal tail length (PTL). Males exhibited a unimodal tendency at a classification interval of 15.0 $\mathrm{cm} \mathrm{MCL}$, and females exhibited a bimodal tendency at 21.0- and $22.0 \mathrm{~cm}$ MCL. Sexual maturity was identified at $12.0 \mathrm{~cm}$ MCL in males and at $12.5 \mathrm{~cm}$ MCL in females. The rate of CWL growth in males was higher at the beginning of sexual maturity and subsequently decreased, whereas in females, the rate of CWL escalated after $19.0 \mathrm{~cm}$ MCL. In both sexes, principal component 1 (PC1) was composed of the variables related to size and $\mathrm{BM}$, and principal component 2 (PC2) and principal component 3 (PC3) were composed of variables related to secondary sex characteristics (CWL and PTL).

Discussion: In members of the genus Trachemys, several secondary sex characteristics can be used to differentiate between the sexes, however, in the present study, recognition of males was performed only by claw length, as it was confirmed by the discriminate analysis and the principal components analysis (PCA) which showed that CWL was the variable that was most discriminatory in males (approximately 76.0\%), followed by BM (approximately 50\%) in females. The results reinforcing the claim that the degree of development of secondary sex characteristics varies between species as well as between distinct populations of the same species and establish that even under unnatural habitat, sexual dimorphism of size in favor of females is maintained for variables related to mass and size.
\end{abstract}

Keywords: covariance, sexual dimorphism index, sex ratio, turtles. 


\section{INTRODUCTION}

Trachemys scripta elegans (T. s. elegans) or Red-Eared slider is an aquatic turtle belonging to the suborder Cryptodira and to the family Emydidae native to North America and is distributed geographically from the eastern United States to northeastern Mexico [36]. In Brazil, it is an exotic and invasive species and the most illegally traded pet animal $[11,36]$. When these turtles grow, they cease to be attractive as pets and are released clandestinely in lakes, ponds, rivers, and other bodies of water where threaten biodiversity $[17,26]$ because they possess a high ecological tolerance and diversified diet, strongly impacting native populations [28].

Report on reproductive biology of turtles shows the presence of sexual size dimorphism, suggesting that smaller males demonstrate earlier maturation [27]. However, characteristics such as greater tail length (precloacal and total), lower body mass, smaller plastron and carapace length, elongate forelimb claws, elongated head, and the occurrence of melanism from the beginning of sexual maturation are not expressed simultaneously in the majority of males in the in the 26 known Trachemys taxa [7,30]. Knowledge of age structure, sex ratio, and morphological variation between the sexes is necessary for the interpretation of ecological processes that act on a population $[2,18]$ and for the development of conservation strategies for a species.

The present study aimed to characterize specimens of T. s. elegans from the Centro de Triagem de Animais Silvestres do Parque Ecológico do Tiete by analyzing body biometrics, sexual dimorphism, and structure of specimens for sex ratio and size classes.

\section{MATERIALS AND METHODS}

Animals

A total of 69 Trachemys scripta elegans turtles (39 females and 30 males), released into the wild and later captured for study by the Wild Animal Triage Center of the Tiete Ecological Park $\left(23^{\circ} 29^{\prime} 23.15^{\prime \prime} \mathrm{S}\right.$, $\left.46^{\circ} 31^{\prime} 10.90^{\prime \prime} \mathrm{W}\right)$, São Paulo, Brazil, were studied. After being anesthetized with a combination of xylazine (20.0 $\mathrm{mg} \mathrm{kg}^{-1}$, Coopazine $\left.{ }^{\circledR}\right)^{1}$ and ketamine (100.0 mg $\mathrm{kg}^{-1}$, Vetanarcol $\left.{ }^{\circledR}\right)^{2}$, administered intraperitoneally with a $25 \times 7$ needle, and euthanized by an infusion of propofol (10-15 mg kg-1, Diprivan) ${ }^{3}$ in the spinal canal using the atlanto-occipital joint. The animals were frozen and sent to the Laboratory of Domestic and Wild Animal Anatomy (Laboratório de Anatomia dos Animais Domésticos e Selvagens - LAADS) of UNIVASF in Petrolina, Pernambuco (PE), Brazil, for research and analysis.

\section{Morphometric evaluations}

After being thawed, the turtles were sexed according to measurements made with calipers with millimeter accuracy on secondary sex characters such as claw length (CWL) of the third finger of the right forearm (length measured in a straight line from the base to the end) and length of the tail from the tip to the beginning of the cloacal opening (postcloacal tail length, PTL); subsequently, sex was confirmed through dissection. When the claw of the third right forefinger was worn or broken, the third left claw was measured. Subsequently, body mass (BM, g) was measured with a digital precision analytic scale $\left(\text { Bioprecisa }^{\circledR}\right)^{4}$ and maximum carapace length (MCL, cm), maximum carapace width (MCW, cm), maximum plastron length (MPL, cm), maximum plastron width (MPW, $\mathrm{cm}$ ) [22] and shell height (HGT, cm, measured laterally until obtaining the greatest value) were evaluated. Body biometrics was established with a caliper with millimeter accuracy and a millimeter measuring tape. The sexual dimorphism index (SDI) [19], consists of a ratio between the sums of averages of the morphological variables of males and females, with the larger sex as the numerator $(\mathrm{SDI}=\mathrm{N} / \mathrm{D})$, was also calculated.

\section{Sexual Confirmation}

The bridge structure, which connects the carapace to the plastron, was removed with a hammer and chisel, allowing the removal of the internal organs and leaving only the urogenital system. Sex was then confirmed, as ovaries with or without follicles and oviducts could be observed in females and the presence of testicles, the epididymis, and the penis could be observed in males. After confirmation of sex, the sex ratio of individuals was obtained (number of females/ number of males).

\section{Statistical Analysis}

The variables were evaluated for normality using the Shapiro-Wilk (W) test. Variables with normal distribution (BM, MPL, MPW, CL, and PTL in females and MCL, MCW, MPL, HGT, and CL in males) were submitted to analysis of variance 
(ANOVA) with a post hoct-test $(P<0.0001)$, and those with non-normal distribution (MCL, MCW, and HGT in females and BM, MPW, and PTL in males) were submitted to ANOVA with a post hocKruskalWallis test $(P<0.01)$. The Pearson correlation test $(P$ $<0.0001)$ was employed to observe the correlation between the variables analyzed, and the analysis of linear regression test was used for sex, using MCL as the independent variable and the remaining variables as dependent variables. Values of $R^{2}>0.70$ and $P<$ 0.0059 were considered significant. Differences in morphometric measurements between sexes were analyzed with analysis of covariance (ANCOVA) and parallel tests to remove the effect of body size in relation to morphometric measurements of males and females. MCL was used as a covariable. The estimate of sexual maturity as a function of secondary sexual dimorphism was obtained through linear regression analysis. The evaluation of the explanation gain of the data presented in the relation between MCL and the other variables was also tested with nonlinear equations. Principal component analysis (PCA) was used to describe the morphological variation between the sexes. Two PCAs were performed, one for females and another for males. Principal factor analysis was also utilized, in which only common variance was used for the estimation of commonalities. Sexual dimorphisms were tested with discriminant analysis using the stepwise and backward methods to evaluate which variables contributed to the differentiation between the sexes. For this, the measurements BM, MCL, MCW, MPL, MPW, HGT, CWL, and PTL were considered independent variables. All analyses were performed using SAS v. 9.4 software.

\section{RESULTS}

Differences in secondary sex characteristics were observed among the 69 individuals studied. Males had greater CWL $(1.52+0.04 ; P<0.0001)$ and smaller PTL $(2.25+0.08 ; P<0.0001)$ than females (Table 1$)$. All Females had tails that were narrower at the base and at the distal end, with the presence of a triangle design on the ventral side to the cloacal opening (Figure 1A), and the cloacal opening ended at the edge of the carapace. In all males the tail was wider at the base and, at the distal end, did not have a triangle design on the ventral sideto the cloacal opening (Figure 1B), and the cloaca extended beyond the edge of the carapace in all males. Thus, taking CWL as a base, 39 females and 30 males were classified and afterwards confirmed by dissection, and the sex ratio was estimated at 1.3 females per one male.

The discriminant function for the sexual differentiation of individuals was estimated utilizing 8 variables, 69 specimens, and two classes, with 39 females and 30 males (Table 1) in a model that proved highly significant. The distribution of the canonical scores demonstrated the separation created by canonical coefficients identified for each variable. This function defined a classification matrix with $100 \%$ accuracy for both sexes, having shown a degree of explanation of $98 \%$ and a significance of $P<0.001$ (Wilk's lambda $=$ $0.13164553: \chi^{2}=93.218$, g.1. $\left.=7\right)$, with a high canonical correlation $(r=0.93)$. Both the multivariate analysis of variance and the discriminant analysis revealed that $100 \%$ (39/39) of females had similar values for the analyzed variables, whereas $96.7 \%$ (29/30) of males had similar values, with $0.03 \%(1 / 30)$ of the male values (BM only) being similar to that of the females.

The multivariate analysis of variance for the discriminant analysis showed that there are significant biometric differences between males and females $(P<$ $0.0001 ; \mathrm{F}=49.47$; Wilk's lambda $=0.1316$ ), with the females larger than the males for all variables, except for CWL, which was, on average, $90 \%$ longer in males than in females. The greatest differences were found for mass and MCL, which were on average 149\% and $26 \%$ greater in females than in males, respectively. The SDI values were in favor of females, with the exception of CWL, which favored males and varied from 1.21 to 2.49, with the greatest value for BM and the lowest value for PTL (Table 1). In the discriminant analysis (stepwise and backward), the variables that most contributed $(P<0.0001)$ in the differentiation between the sexes were CWL $\left(R^{2}=0.7864\right.$ and 0.6024 , respectively) and $\mathrm{BM}\left(R^{2}=0.3256\right.$ and 0.3256 , respectively (Table 2).

The frequency distribution by size classes, based on the MCL of males and females and constructed on the basis of predetermined intervals in the methodology, had a normal distribution for males and a non-normal distribution for females. Males had their mode MCL at the $15.0 \mathrm{~cm}$ class interval, whereas for the females, the mode occurred at 21.0 and $22.0 \mathrm{~cm}$, thus indicating a unimodal tendency in males and a bimodal tendency in females (Figure 2) in this sampled population. 

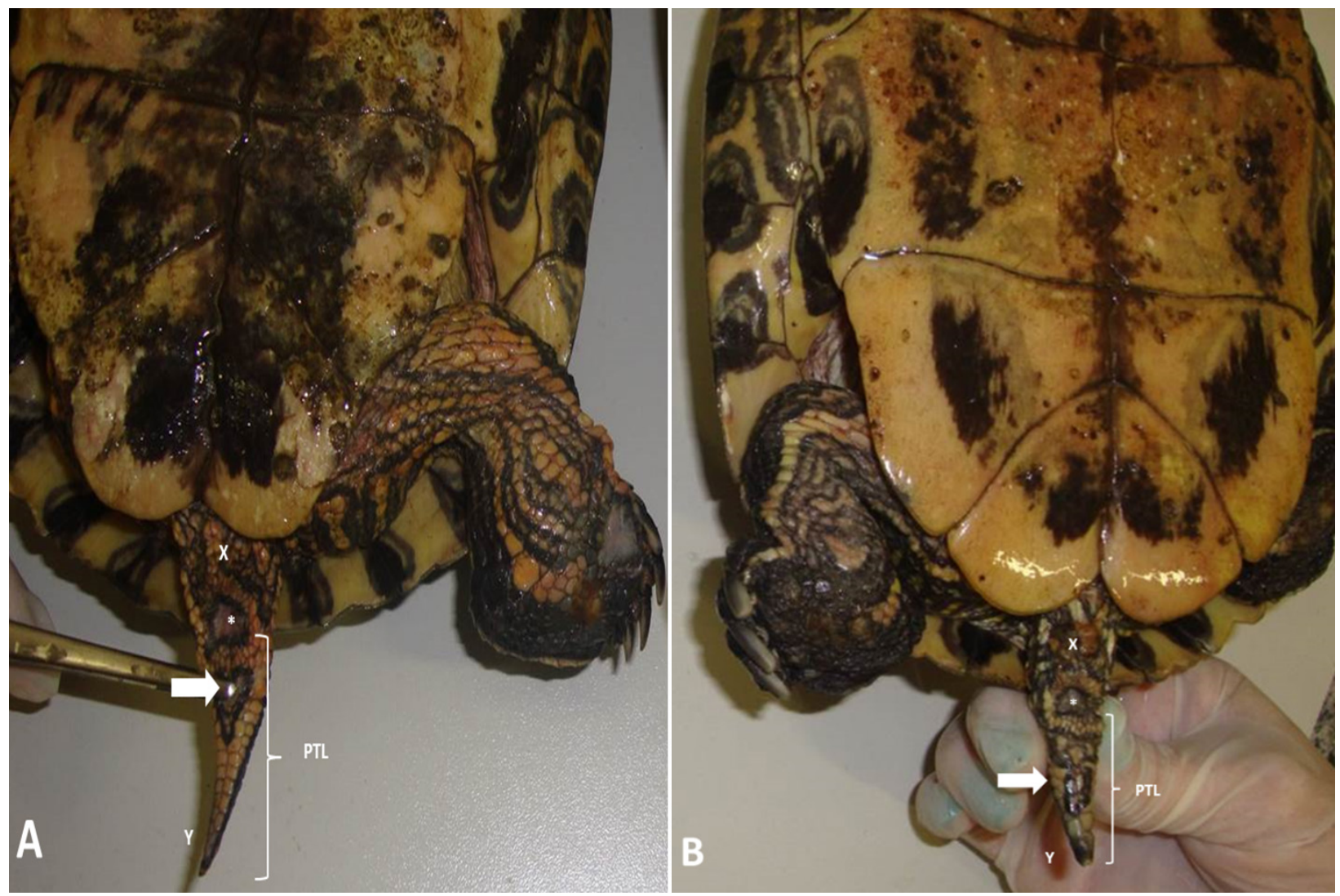

Figure 1. Photograph showing the different morphologies observed for the tails of T. scripta elegans from the Tiete Ecological Park, São Paulo, Brazil. A- In females, the tail is narrower at the base (X) and, at the distal end (Y), has a triangular design (arrow) on its ventral side distal to the cloacal opening $(*)$, which opening ended at the edge of the carapace and had longer postcloacal tail length (PTL). B- In males, the tail was wider at the base $(\mathrm{X})$ and at the distal end $(\mathrm{Y})$, did not have a design in the form of a triangle (arrow) caudal to the cloacal opening $(*)$, which extended beyond the edge of the carapace and had a shorter PTL.

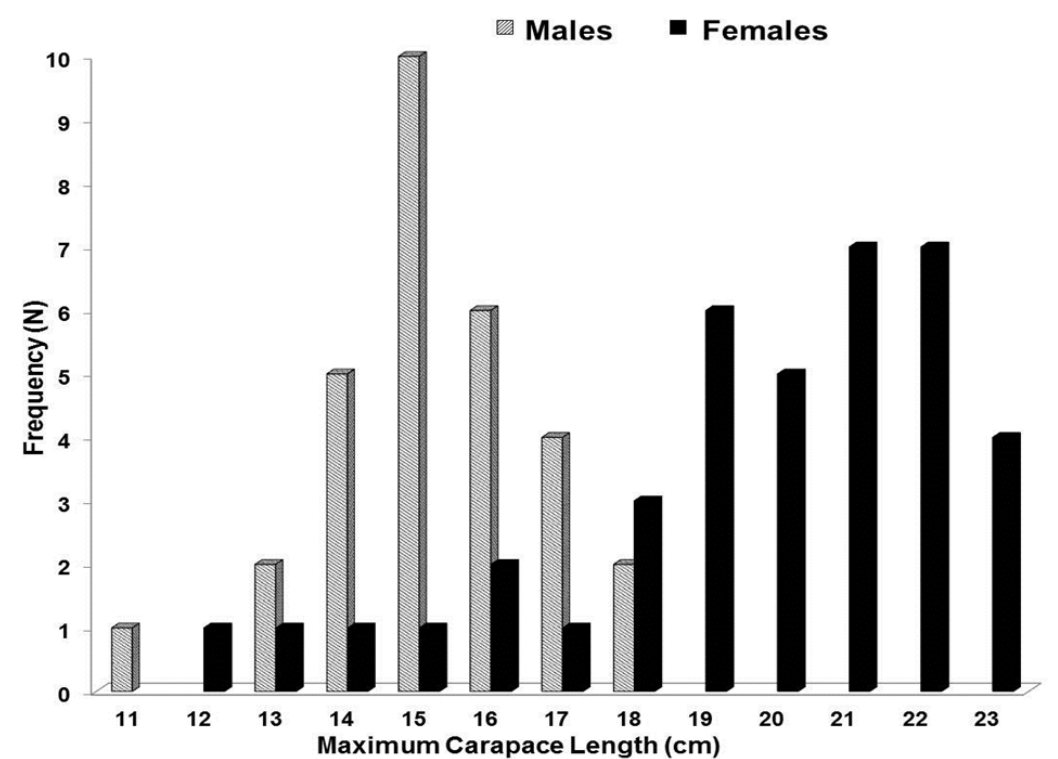

Figure 2. Frequency distribution of the maximum carapace length $(\mathrm{cm})$ in males and females of Trachemys scripta elegans from the Tiete Ecological Park, São Paulo, Brazil. 
Table 1. Descriptive statistics of measured morphological variables and the sexual dimorphism index in Trachemys scripta elegans captured in the Tiete Ecological Park, São Paulo, Brazil.

\begin{tabular}{|c|c|c|c|c|c|c|c|}
\hline & \multicolumn{3}{|c|}{ Males } & \multicolumn{3}{|c|}{ Females } & \multirow[b]{2}{*}{ SDI } \\
\hline & Average \pm SEM & Min./Max & No. & Average \pm SEM & Min./Max & No. & \\
\hline $\mathrm{BM}$ & $477.74 \pm 20.53^{a}$ & $382.0 / 992.0$ & 30 & $1193.12 \pm 55.50^{b}$ & $551.4 / 1805.3$ & 39 & 2.49 \\
\hline MCL & $15.56 \pm 0.27^{\mathrm{a}}$ & $11.9 / 18.9$ & 30 & $20.03 \pm 0.46^{\mathrm{b}}$ & $15.4 / 23.9$ & 39 & 1.29 \\
\hline $\mathrm{MCW}$ & $12.14 \pm 0.17^{\mathrm{a}}$ & $10.3 / 15.0$ & 30 & $15.33 \pm 0.47^{\mathrm{b}}$ & $12.2 / 22.0$ & 39 & 1.26 \\
\hline MPL & $13.91 \pm 0.22^{\mathrm{a}}$ & $11.1 / 18.2$ & 30 & $18.78 \pm 0.38^{b}$ & $13.9 / 22.9$ & 39 & 1.35 \\
\hline MPW & $9.26 \pm 0.13^{\mathrm{a}}$ & $6.2 / 12.2$ & 30 & $11.85 \pm 0.26^{\mathrm{b}}$ & $9.0 / 15.4$ & 39 & 1.28 \\
\hline HGT & $5.37 \pm 0.11^{\mathrm{a}}$ & $4.1 / 8.9$ & 30 & $7.57 \pm 0.27^{b}$ & $4.2 / 10.0$ & 39 & 1.41 \\
\hline CWL & $1.52 \pm 0.04^{\mathrm{a}}$ & $0.9 / 1.9$ & 30 & $0.80 \pm 0.02^{b}$ & $0.6 / 1.1$ & 39 & 1.90 \\
\hline PTL & $2.25 \pm 0.08^{a}$ & $1.5 / 2.8$ & 30 & $2.72 \pm 0.11^{\mathrm{b}}$ & $1.8 / 3.8$ & 39 & 1.21 \\
\hline
\end{tabular}

a,bValues of BM, MPL, MPW, CWL, PTL in females and of MCL, MCW, MPL, HGT, CWL in males differ according to the t-test $(P<0.0001)$ and a,b Values of MCL, MCW, HGT in females and of BM, MPW, PTL in males differ according to the Kruskal-Wallis test $(P<0.01)$. SEM Standard Error Of The Mean; Min/Max: minimum value/maximum value; No.: total number of animals; SDI: sexual dimorphism index (average value of larger sex/ average value of smaller sex). BM: body mass; MCL: maximum straight-line carapace length; MCW: Maximum carapace width; MPL: maximum plastron length; MPW: maximum plastron width; HGT: shell height; CWL: claw length; PTL: postcloacal tail length.

Table 2. Morphological variables that most contributed to the differentiation between the sexes $(P<0.0001)$ according to discriminant analysis of biometric data of Trachemys scripta elegans from the Tiete Ecological Park, São Paulo, Brazil.

\begin{tabular}{cccccccc}
\hline & \multicolumn{3}{c}{ Stepwise } & & \multicolumn{3}{c}{ Bachward } \\
\cline { 2 - 3 } \cline { 7 - 8 } Variable & $R^{2}$ & $F$ Value & $\operatorname{Pr}>F$ & & $R^{2}$ & $F$ Value & $\operatorname{Pr}>F$ \\
\hline BM & 0.3256 & 31.87 & $<0.0001$ & & 0.3256 & 31.87 & $<0.0001$ \\
MCL & 0.0083 & 0.54 & 0.4631 & & 0.0287 & 1.89 & 0.1740 \\
MCW & 0.0222 & 1.48 & 0.2289 & & 0.0156 & 0.98 & 0.3256 \\
MPL & 0.0125 & 0.82 & 0.3681 & & 0.0125 & 0.82 & 0.3681 \\
MPW & 0.0077 & 0.50 & 0.4815 & & 0.0050 & 0.31 & 0.5808 \\
HGT & 0.0117 & 0.77 & 0.3829 & & 0.0224 & 1.44 & 0.2340 \\
CWL & 0.7864 & 246.63 & $<0.0001$ & & 0.6024 & 100.02 & $<0.0001$ \\
PTL & 0.0015 & 0.10 & 0.7559 & & 0.0050 & 0.30 & 0.5840 \\
\hline
\end{tabular}

BM: body mass; MCL: maximum carapace length; MCW: Maximum carapace width; MPL: maximum plastron length; MPW: maximum plastron width; HGT: height; CWL: claw length; PTL: postcloacal tail length.

In males, a significant, positive correlation was observed $(P<0.0001)$ between MCL and MCW $(\mathrm{r}=$ $0.70874)$; between MCW and MPL $(r=0.71287)$ and MPW ( $\mathrm{r}=0.85014)$; between MPL and MPW ( $\mathrm{r}=$ $0.78828)$ and HGT $(r=0.69705)$; and in females between BM and MCL $(r=0.84821)$, MCW $(r=0.60052)$, MPL ( $r=0.90023)$, and MPW $(r=0.68371)$; between MCL and MPL $(r=0.87516)$, MPW $(r=0.60594)$, and HGT $(r=0.61488)$; and between MPL and MPW $(r=0.68008)$.

The linear regression analyses performed with MCL as the independent variable and the other variables as dependent variables showed that the line corresponding to males differed at $12.0 \mathrm{~cm} \mathrm{MCL}$, and the line corresponding to females, at $12.5 \mathrm{~cm}$ MCL. All equations had significant correlation coefficients, except for CWL $\left(R^{2}=0.00118, P=0.57\right)$ and PTL $\left(R^{2}=\right.$
$0.0011, P=0.8632)$ for males and for CWL $\left(R^{2}=0.03\right.$, $P<0.30)$ for females. Males had the highest coefficient of determination in the equation calculated between $\mathrm{MCL}$ and MCW $\left(\mathrm{MCW}=5.19+0.45 \times \mathrm{MCL} ; R^{2}=\right.$ 0.50 ) and for females, between MCL and MPL (MPL $\left.=4.40+0.72 \times \mathrm{MCL}, R^{2}=0.77\right)$, whereas the lowest coefficient was observed between MCL and PTL for males $\left(\mathrm{PTL}=2.10+0.01 \times \mathrm{MCL} ; R^{2}=0.0011\right)$ and between MCL and CWL for females $(\mathrm{CWL}=0.63+$ $0.01 \times$ MCL; $R^{2}=0.03$ ).

The analyses of covariance with the variable sex classification and covariable MCL showed a significant difference for MCL and for the interaction SEX x MCL when analyzed for BM; for MCL when analyzed for MCW, MPL, MPW, and HGT; for SEX when analyzed for CL; and no significant difference when analyzed for PTL (Table 3). 
In males, $75.64 \%$ of the variance found was explained up to the third PC, with principal component 1 (PC1) explaining $49.42 \%$ of the variance, PC2 explaining $14.91 \%$, and PC3 explaining $11.31 \%$. In females, $78.77 \%$ of the variance found between the sexes was explained up to the third principal component (PC), with PC1 explaining 52.34\% of the variance, PC2 explaining $13.85 \%$, and PC3 explaining $12.58 \%$. In males and in females, $\mathrm{PC} 1$ was composed of variables related to size (MCL, MCW, MPL, and MPW) and BM, and PC2 and PC3 were composed of variables related to secondary sex characteristics (CWL and PTL). Table 4 shows the Pearson correlation observed among the body biometrics, biometrics of secondary sex characteristics, and the principal components (PC1, PC2, and PC3) in T. s. elegans.
In the analysis of principal factors, two factors (F1 and F2) were retained by the NFACTOR criterion. The variance explained for each factor in males was $76.82 \%$ for $\mathrm{F} 1$ and $23.18 \%$ for $\mathrm{F} 2$, and in females $79.07 \%$ and $20.93 \%$, respectively. The pattern of each factor for each variable analyzed and the final estimates of commonalities for females (total $=5.295189$ ) and males (total $=5.146081$ ) are described in Table 5. For females, the variables BM, MCL, MCW, MPL, and MPW were positively correlated $(P<0.0001)$ with F1, whereas CWL and PTL were positively correlated $(P<$ $0.0001)$ with F2. In males, the variables MCL, MCW, MPL, MPW, and HGT were positively correlated $(P$ $<0.0001)$ with F1, whereas CWL was positively correlated $(P<0.0001)$ with $\mathrm{F} 2$, and PTL was negatively correlated $(P<0.0001)$ with $\mathrm{F} 2$.

Table 3. Analysis of covariance of body morphometrics in Trachemys scripta elegans from the Tiete Ecological Park, São Paulo, Brazil, considering the interactions of sex, maximum carapace length (MCL), and MCL and sex.

\begin{tabular}{cccc}
\hline Variable & \multicolumn{3}{c}{ Interaction } \\
\cline { 2 - 4 } & SEX & MCL & MCL * SEX \\
\hline BM & $P=0.0265$ & $P<0.0001$ & $P=0.0021^{*}$ \\
MCW & $P=0.7863$ & $P=0.0025^{*}$ & $P=0.9897$ \\
MPL & $P=0.5544$ & $P<0.0001$ & $P=0.1797$ \\
MPW & $P=0.8658$ & $P=0.0001^{*}$ & $P=0.5323$ \\
HGT & $P=0.2974$ & $P=0.0007^{*}$ & $P=0.1747$ \\
CWL & $P=0.0087^{*}$ & $P=0.7501$ & $P=0.3283$ \\
PTL & $P=0.2783$ & $P=0.1527$ & $P=0.2414$ \\
\hline
\end{tabular}

BM: body mass; MCW: Maximum carapace width; MPL: maximum plastron length; MPW: maximum plastron width; HGT: height; CWL: claw length; PTL: postcloacal tail length.

Table 4. Pearson correlation observed between body biometrics, biometrics of secondary sex characteristics, and principal components (PC1, PC2, and PC3) and their levels of significance in Trachemys scripta elegans from the Tiete Ecological Park, São Paulo, Brazil.

\begin{tabular}{|c|c|c|c|c|c|c|c|c|c|c|}
\hline Variable & MCL & MCW & MPL & MPW & HGT & CWL & PTL & PC1 & $\mathrm{PC} 2$ & PC3 \\
\hline \multirow{2}{*}{$\mathrm{BM}$} & 0.90 & 0.75 & 0.94 & 0.84 & 0.76 & -0.68 & 0.44 & 0.49 & -0.08 & 0.03 \\
\hline & $<.0001$ & $<.0001$ & $<.0001$ & $<.0001$ & $<.0001$ & $<.0001$ & 0.0002 & $<.0001$ & 0.4951 & 0.8188 \\
\hline \multirow{2}{*}{ MCL } & & 0.67 & 0.91 & 0.79 & 0.77 & -0.59 & 0.49 & 0.62 & -0.0002 & -0.05 \\
\hline & & $<.0001$ & $<.0001$ & $<.0001$ & $<.0001$ & $<.0001$ & $<.0001$ & $<.0001$ & 0.9987 & 0.7055 \\
\hline \multirow{2}{*}{ MCW } & & & 0.67 & 0.63 & 0.55 & -0.53 & 0.34 & 0.48 & -0.28 & -0.14 \\
\hline & -- & ---- & $<.0001$ & $<.0001$ & $<.0001$ & $<.0001$ & 0.0046 & $<.0001$ & 0.0182 & 0.2604 \\
\hline \multirow{2}{*}{ MPL } & & & & 0.86 & 0.74 & -0.67 & 0.44 & 0.55 & 0.002 & 0.04 \\
\hline & ---- & & ---- & $<.0001$ & $<.0001$ & $<.0001$ & 0.0002 & $<.0001$ & 0.9862 & 0.7376 \\
\hline \multirow{2}{*}{ MPW } & & & & & 0.62 & -0.59 & 0.29 & 0.52 & -0.09 & 0.22 \\
\hline & & & $-\cdots$ & & $<.0001$ & $<.0001$ & 0.0174 & $<.0001$ & 0.4725 & 0.0651 \\
\hline \multirow{2}{*}{ HGT } & -3 & -8 & -8 & & & -0.53 & 0.45 & 0.48 & 0.16 & -0.14 \\
\hline & & & & & & $<.0001$ & $\begin{array}{c}0.0001 \\
-0.31\end{array}$ & $\begin{array}{c}<.0001 \\
0.02\end{array}$ & $\begin{array}{c}0.1840 \\
0.32\end{array}$ & $\begin{array}{c}0.2414 \\
0.26\end{array}$ \\
\hline CWL & ----- & ----- & ----- & ------ & ----- & ----- & 0.0083 & 0.8817 & 0.0063 & 0.0340 \\
\hline \multirow[t]{2}{*}{ PTL } & ----- & ----- & ----- & ----- & ----- & ----- & ----- & 0.28 & 0.11 & -0.13 \\
\hline & & & & --- & - & $\cdots$ & $\cdots$ & 0.0178 & 0.3827 & 0.2952 \\
\hline
\end{tabular}

BM: body mass; MCL: maximum carapace length; MCW: Maximum carapace width; MPL: maximum plastron length; MPW: maximum plastron width; HGT: height; CWL: claw length; PTL: postcloacal tail length. 
Table 5. Scores of principal factors and commonalities (measure of the proportion of variance explained by extracted factors) of analyses of morphological differences in Trachemys scripta elegans from the Tiete Ecological Park, São Paulo, Brazil.

\begin{tabular}{cccccccc}
\hline & \multicolumn{3}{c}{ Females } & & \multicolumn{3}{c}{ Males } \\
\cline { 1 - 1 } \cline { 7 - 8 } Variable & Factor 1 & Factor 2 & Commonalities & & Factor 1 & Factor 2 & Commonalities \\
\hline BM & 0.92045 & 0.26225 & 0.91599616 & & 0.61253 & -0.32827 & 0.48295451 \\
MCL & 0.84222 & 0.38194 & 0.85522100 & & 0.76499 & -0.11976 & 0.59954975 \\
MCW & 0.72362 & 0.19968 & 0.56349514 & & 0.87440 & -0.14679 & 0.78611559 \\
MPL & 0.86534 & 0.31616 & 0.84876818 & & 0.89785 & 0.04811 & 0.80844716 \\
MPW & 0.75265 & 0.10076 & 0.57663709 & & 0.88590 & -0.00924 & 0.78490725 \\
HGT & 0.51231 & 0.47965 & 0.49252773 & & 0.76963 & 0.14720 & 0.61400140 \\
CWL & 0.00721 & 0.73926 & 0.54656105 & & -0.08290 & 0.76666 & 0.59463353 \\
PTL & 0.18122 & 0.68055 & 0.49598279 & & -0.02339 & -0.68915 & 0.47547230 \\
\hline
\end{tabular}

BM: body mass; MCL: maximum carapace length; MCW: Maximum carapace width; MPL: maximum plastron length; MPW: maximum plastron width; HGT: height; CWL: claw length; PTL: postcloacal tail length.

\section{DISCUSSION}

The expression of secondary sex characters, as well as sexual dimorphism and sex ratio, were evaluated in a population of T. s. elegans, an exotic species in Brazil whose illegal trade has resulted in the indiscriminate abandonment of specimens in water bodies such as those found in the Tiete Ecological Park. Though in members of the genus Trachemys, several secondary sex characteristics can be used to differentiate between the sexes $[21,25,30,34]$, in the present study, recognition of males was performed only by claw length. Longer claws in males occur in $T$. dorbignyi $[6,10,27,33,35,36]$ and T. scripta [28], differing from T. adiutrix [7]. Other studies have reported the tail as the largest variable observed in males, being wider at the base $[9,10,12,16,24,33]$ and longer $[7,9,16,33]$. In the present study, tails wider at the base and at the tip were noted, with the length from the tip of the tail to the beginning of the cloaca (PTL) being smaller in males. This finding differed from others characteristics such as greater tail length (precloacal and total) observed in the majority of males [7,30] and reinforced the claim that the degree of development of secondary sex characteristics varies between species as well as between distinct populations of the same species [19].

Corroborating the literature $[6,9,10,27,33,36]$, the cloacal opening in males extended beyond the edge of the carapace, which was not observed in females. However, the presence of a triangle-like design on the ventral side of the tail, caudal to the cloacal opening, as observed in females, has not been described in the literature, once again reinforcing the existence of variation in the degree of development of secondary sex characteristics between species of Trachemys as well as between distinct populations of T. s. elegans.

Regarding CWL, male maturity was identified at $12.0 \mathrm{~cm}$ MCL, agreeing with others [6], although this value was inferior to that of T. dorbignyi $[6,16]$ and superior to that of T. scripta from Illinois [27]. In females, sexual maturity occurred when the MCL reached $12.5 \mathrm{~cm}$, a lower value than those others $[6,20]$.

The absence of a significant difference in the slope coefficient in the parallelism analysis of CWL indicated that in males, there is a high rate of CWL growth as soon as sexual maturation is initiated followed by a slowing of post-maturity CWL growth, whereas in females, the CWL growth rate accelerates after achieving a $19.0 \mathrm{~cm}$ MCL. The correlation coefficient calculated between MCL and CWL for the equations of both sexes was lower than for the other variables analyzed, possibly because CWL is not related to MCL but is related to sex.

Differences and limitations of ecological and physiological requirements between the sexes, mortality rates, maximum sizes attained by males and females, and greater reproductive success as related to size appear to be the causes of sexual dimorphism in body size $[1,31]$. The discriminate analysis and the principal components analysis (PCA) showed that CWL was the variable that was most discriminatory (approximately $76.0 \%$ ), followed by BM (approximately 50\%). The pattern of distribution of characteristics that make up the principal components disagreed with that suggested by Silva [31], in which the characteristics for PC1 referred to size and mass, and for PC2, to those related to shape. CWL was the variable most discriminatory in 
males, whereas in females were best distinguished by BM. CWL was predicted to be relevant in males due to the high use of claws in the mating ritual [7], whereas $\mathrm{BM}$ was expected to be relevant in females due to its high correlation with variables related to the carapace and plastron and, consequently, to an increase in reproductive potential. Larger females produce clutches with a greater number and size of eggs and can lay a greater number of clutches per reproductive period $[5,7]$. At dissection, all females had a large number of vitellogenic eggs of different sizes and degrees of shell formation, justifying their larger mass in comparison to males. Female biased sexual size dimorphism also occurs in Trachemys dorbignyi [5,8,16,32]; T. scripta [27]; T. adiutrix [7] and P. expansa [29], while larger males occur in Geochelone carbonaria and G. denticulata [29] and in Clemmys insculpta [20].

The SDI for different populations of the genus Trachemys varies from 1.09 to 1.61 [19], from 1.18 to 1.19 for T. callirostris [23], and from -0.49 to 2.05 for T. adiutrix [7], all favoring females. In this study, the SDI varied from 1.21 to 2.49 in favor of females, with the exception of CWL, which favored males (1.90). The highest SDI value was observed for BM and was much higher than in T. adiutrix. Our SDI values for MPL, HGT, and CWL were also higher than in this species, whereas the values for MCL, MCW, and MPW were similar [7].

The rate of growth of the variable MCL was different between males and females and influenced the increase of BM, MCW, HGT, and variables related to the plastron, whereas the variable CWL was influenced only by sex. Although species of the genus Trachemys can reach between 20.0 and $60.0 \mathrm{~cm}$ in carapace length as adults [6] were observed values from 13.2 to $20.0 \mathrm{~cm}$ for males and from 18.6 to $29.2 \mathrm{~cm}$ for females [19], corroborating the average values of the present study. However, the minimum and maximum values of MCL, both for males and for females, were lower than those values observed by these authors. The unimodal tendency of MCL observed for males was also described in males of $T$. dorbignyi $[5,8,15,33]$ as well as in other populations of $T$. scripta [21], whereas the bimodal tendency observed for females was described only in males of Podocnemis unifilis [13] and in females of Podocnemis sextuberculata. The bimodal tendency appears to be a reflection of slower growth during one stage of the animal's life [14].
After dissection and confirmation of sex, the sex ratio was shown to be slightly asymmetric (1.03 females for 1 male). It is believed that the determinant factor for this asymmetric sex ratio is due to differential availability of the sexes in the pet trade and their release into the wild. The fact that all specimens were adults and that females were significantly larger reinforces this claim, as the abandonment of T. s. elegans occurs when they reach larger sizes and cease to be attractive as pets. A sex ratio differing from 1:1 and female-biased was also described by others [33] and contrasted with the ratio in favor of males described for T. dorbignyi [5,16], T. adiutrix [7] and T. scripta in Florida [3,4].

\section{CONCLUSIONS}

In conclusion, our results supported that even under unnatural conditions, sexual dimorphism and size in favor of females are maintained for variables related to mass and size. The length of the claws in males is the only differentiating secondary sex factor, which reinforces the existence of differences in the degree of development of secondary sex characteristics between species and between distinct populations of Trachemys scripta elegans.

\section{MANUFACTURERS}

${ }^{1}$ Coopers Brasil Ltda. Produtos Químicos. Cotia, SP, Brazil.

${ }^{2}$ Konig Brasil. São Paulo, SP, Brazil.

${ }^{3}$ Wellcome Laboratories - ICI Ltda. Cotia, SP, Brazil

${ }^{4}$ Labmais Ltda. Curitiba, PR, Brazil.

${ }^{5}$ SAS v. 9.4 software.

Funding. We thank the National Council of Scientific and Technological Development (CNPq), Pernambuco Science And Technology Support Foundation (FACEPE) and the Federal University of the San Francisco Valley (UNIVASF) for the research grants.

Ethical approval. The study was approved by the IBAMA (license $n^{\circ} 136 / 2011$ ) and from the Ethics Committee on the Use of Animals of the Federal University of the San Francisco Valley under Protocol no. 0001/160412.

Acknowledgments. We thank the Brazilian Institute of Environment and Renewable Natural Resources (InstitutoBrasileiro do MeioAmbiente e dos RecursosNaturaisRenováveis - IBAMA) for providing work licenses and from the Tiete Ecological Park for providing the animals.

Declaration of interest. The authors declare that they have no conflict of interest. The authors alone are responsible for the content and writing of paper. 


\section{REFERENCES}

1 Anderson R.A. \& Vitt L.J. 1990. Sexual selection versus alternative causes of sexual dimorphism in teiid lizards. Oecologia. 84(2): 145-157.

2 Aponte C., Barreto G.R. \& Terborgh J. 2003. Consequences of habitat fragmentation on age structure and life history in a tortoise population. Biotropica. 35(4): 550-555.

3 Aresco M.J. 2005. The effect of sex-specific terrestrial movements and roads on the sex ratio of freshwater turtles. Biological Conservation. 123(1): 37-44.

4 Aresco M.L. \& Dobie J.L. 2000. Variation in shell arching and sexual size dimorphism of River Cooters, Pseudemys concinna, from two river systems in Alabama. Journal of Herpetology. 34 (2): 313-317.

5 Bager A., Freitas T.R.O. \& Krause L. 2010. Morphological characterization of adults of Orbigny's Slider Trachemys dorbignyi (Duméril\&Bibron 1835) (Testudines, Emydidae) in southern Brazil. Tropical Zoology. 23(2): 181-194.

6 Bager A. 2003. Aspectos da biologia e ecologia da tartaruga tigre d'água, Trachemys dorbignyi (Testudines, Emydidae) no extremo sul do Rio Grande do Sul - Brasil. 110f. Porto Alegre, RS. Tese (Doutorado em Ecologia) - Programa de Pós-graduação em Ecologia, Universidade Federal do Rio Grande do Sul. [Fonte: http://www.lume.ufrgs.br/bitstream/ handle/10183/3441/000400598.pdf?sequence=1]. [Accessed online in October 2016].

7 Batistella A.M. 2008. Biologia de Trachemys adiutrix (Vanzolini, 1995) (Testudines, Emydidae) no litoral do NordesteBrasil. 82f. Manaus, AM. Tese (Doutorado em Ciências Biológicas) - Programa de Pós-graduação em Biologia Tropical e Recursos Naturais, Universidade Federal do Amazonas.

8 Bujes C. S., Molina F.N. \& Verrastro L. 2011. Population characteristics of Trachemys dorbignyi (Testudines, Emydidae) from delta do Jacuí state park, Rio Grande do Sul, Southern Brazil. South American Journal of Herpetology. 6(1): 27-34.

9 Bujes C.S. 2010. Os Testudines continentais do Rio Grande do Sul, Brasil: taxonomia, história natural e conservação. Iheringia Série Zoologia. 100(4): 413-424.

10 Cabrera M.R. 1998. Las tortugas continentales de Sudamérica Austral. Córdoba: Talleres gráficos BR Copias, 108p.

11 Caldogneto L., Puorto G. \& Serapicos E.O. 2002. Estudo dos valores glicêmicos em Trachemys scripta elegans mantidas em cativeiro. In: Proceedings of the XXIV Congresso Brasileiro de Zoologia (Itajaí, Brazil). p.448.

12 Ely I. 2008. Área de vida, movimento e hábitat utilizado por Trachemys adiutrix Vanzolini, 1995 (Testudines - Emydidae) na região dos pequenos Lençóis Maranhenses, Brasil. 69f. Porto Alegre, RS. Dissertação (Mestrado em Biologia Animal) - Programa de Pós-graduação em Biologia Animal, Universidade Federal do Rio Grande do Sul.

13 Fachín-Terán A. \& Vogt R.C. 2004. Estrutura populacional, tamanho e razão sexual de Podocnemis unifilis (Testudines, Podocnemididae) no rio Guaporé (RO), norte do Brasil. Phyllomedusa. 3(1): 29-42.

14 Fachín-Terán A., Vogt R.C. \& Thorbjarnarson J.B. 2003. Estrutura populacional, razão sexual e abundância de Podocnemis sextuberculata (Testudines, Podocnemididae) na Reserva de Desenvolvimento Sustentável Mamirauá, Amazonas, Brasil. Phyllomedusa. 2(1): 43-63.

15 Fagundes C.K., Bager A. \& Cechin S.T.Z. 2010. Trachemys dorbignyi in an anthropic environment in southern Brazil: I) Sexual size dimorphism and population estimates. Herpetologica Journal. 20(3): 185-193.

16 Fagundes C.K. 2007. Dinâmica populacional de Trachemys dorbignyi (Testudines: Emydidae) em ambiente antrópico em Pelotas, RS. 82f. Santa Maria, RS. Dissertação (Mestrado em Biodiversidade Natural) - Programa de Pós-graduação em Ciências Biológicas - Biodiversidade Animal, Universidade Federal de Santa Maria.

17 Fonseca F.O. 2001. Olhares sobre o lago Paranoá. Brasília: SEMARH, 425 pp.

18 Gibbons J.W., Lovich J.E., Tucker A.D., Fitzsimmons N.N. \& Greene J.L. 2001. Demographic and ecological factors affecting conservation and management of the Diamondback Terrapin (Malaclemys terrapin) in South Carolina. Chelonian Conservation and Biology. 4(1): 66-74.

19 Gibbons J.W. \& Lovich J.E. 1990. Sexual dimorphism in turtles with emphasis on the slider turtle (Trachemys scripta). Herpetological Monographs. 4: 1-29.

20 Lovich J.E., Ernst C.H. \& McBreen J.F. 2014. Growth, maturity, and dimorphism sexual in the wood turtle, Clemmys insculpta. Canadian Journal of Zoology. 68(4): 672-677.

21 Lovich J.E., McCoy C.J. \& Garstka W.R. 1990. The development and significance of melanism in the slider turtle. In: Gibbons J.W. (Ed). Life History and Ecology of the Slider Turtle. Washington D.C.: Smithsonian Institution Press, pp.233-254. 
22 Malvasio A., Gomes N. \& Farias E.C. 1999. Identificação sexual através do estudo anatômico do sistema urogenital em recém-eclodidos e jovens de Trachemys dorbignyi (Duméril \& Bibron) (Reptilia, Testudines, Emydidae). Revista Brasileira de Zoologia. 16(1): 91-102.

23 Marin A.S., Marulanda M.A. \& Obeid F.S. 2003. Aspectos de la morfometria de la Jicoteca Colombiana (Trachemys scripta callirostris: Chelonia, Emydidae) y sus possibles ventajas para la supervivencia. Revista Biologia. 17: 114-119.

24 Mateus I.F. 2014. Patologia e clínica de animais exóticos e autóctones. 127f. Évora, Portugal. Dissertação (Mestrado Integrado em Medicina Veterinária), Universidade de Évora.

25 Moll D. \& Moll E.O. 2004. The ecology, exploration, and conservation of river turtles. Oxford: Oxford University, 420pp.

26 Primack R.B. \& Rodrigues E. 2001. Biologia da Conservação. Londrina: Editora Planta, 327pp.

27 Readel A.M., Warner J., Holberton R.L. \& Phillips C.A. 2008. Maturational changes in male slider turtles (Trachemys scripta) from Illinois. Herpetological Conservation and Biology. 3(2): 170-175.

28 Rocha D.F.N.B. 2005. Biologia termal das tartarugas Trachemys dorbignyi (Duméril \& Bibron, 1835) e Trachemys scripta elegans (Wied, 1839) nos lagos de Porto Alegre, RS, Brail (Testudines, Emydidae). 79f. Porto Alegre, RS. Dissertação (Mestrado em Biologia Animal) - Programa de Pós-graduação em Biologia Animal, Universidade Federal do Rio Grande do Sul.

29 Salera-Júnior G. 2005. Avaliação da biologia reprodutiva, predação natural e importância social em quelônios com ocorrência na bacia do Araguaia. 202f. Palmas, TO. Dissertação (Mestrado em Ciências do Ambiente) - Programa de Pós-graduação em Ciências do Ambiente, Universidade Federal do Tocantins.

30 Seidel M.E. 2002. Taxonomic observations on extant species and subspecies of slider turtles, genus Trachemys. Journal of Herpetology. 36(2): 258-292.

31 Silva T.L. 2011. Estudo morfológico e citogenético em duas espécies de jabutis do gênero Chelonoidis (Fitzinger, 1835) (Testudines). 117f. São José do Rio Preto, SP. Dissertação (Mestrado em Biologia Animal) - Programa de Pósgraduação em Biologia Animal, Universidade Estadual Paulista Júlio de Mesquita Filho.

32 Silveira M.L. 2013. Variação morfológica e populacional de Trachemys dorbignyi (Testudines, Emydidae) no extremo sul do Brasil. 88f. Lavras, MG. Dissertação (Mestrado em Ecologia Aplicada) - Programa de Pós-graduação em Ecologia Aplicada, Universidade Federal de Lavras.

33 Silveira M.L., Hartmann M.T. \& Bager A. 2012. Biometria, razão sexual e dimorfismo sexual de Trachemys dorbigni (Duméril\&Bibron 1835) (Testudines, Emydidae) em um açude no município de São Gabriel, Rio Grande do Sul, Brasil. Biotemas. 25(3): 187-193.

34 Thomas R.B. 2006. Trachemys scripta- Slider or Yellow-Bellied Slider. In: Meylan P.A. (Ed.). Biology and Conservation of Florida Turtles. Chelonian Research Monographs. 3:297-312.

35 Thomas R.B. 2002. Conditional mating strategy in a long-lived vertebrate: ontogenetic shifts in the mating tactics of male Slider Turtles (Trachemys scripta). Copeia. 2(2): 456-461.

36 Vieira C.S. \& Costa E.M.E. 2006. Análise da estrutura populacional de Trachemys scripta elegans (Chelonia) no Parque Ecológico Olhos D’água - Brasília - DF. Universidades: Ciências da Saúde. 4: 1-8. 